\title{
Public work projects cultivate youth in workforce development programs
}

\author{
By David Campbell, Jean Lamming, \\ Cathy Lemp, Ann Brosnahan, Carole Paterson \\ and John Pusey
}

\section{Using comparative case studies, we} evaluated youth workforce development programs in California that are funded by the Workforce Investment Act (WIA) and implemented by local Youth Councils and Workforce Investment Boards. First, we identified a promising practice: skill- and pridegenerating public work projects. Next, we identified three characteristics of these successful youth public work initiatives: (1) combining employment preparation with social services and personal support; (2) grouping youth in cohorts that work and learn together; and (3) providing caring adult supervision that combines discipline and support. Proactive investments in high-quality programs with these characteristics can reduce the growing number of out-of-school, out-ofwork youth in California, save future public costs for the criminal justice and social service systems, and provide youth with meaningful employment opportunities.

For more than 2 decades, former Sec1 retary of Labor Robert Reich (now a University of California, Berkeley, professor) has championed the idea that our national security depends on increasing public investment in education and workforce training (Reich 1983, 1991, 2002). In his 1991 book The Work of Nations, Reich wrote that rather than enhancing the profitability of its corporations or the worldwide holdings of its citizens, the nation's primary economic role is to "improve its citizens' standard of living by enhancing the value of what they contribute to the world

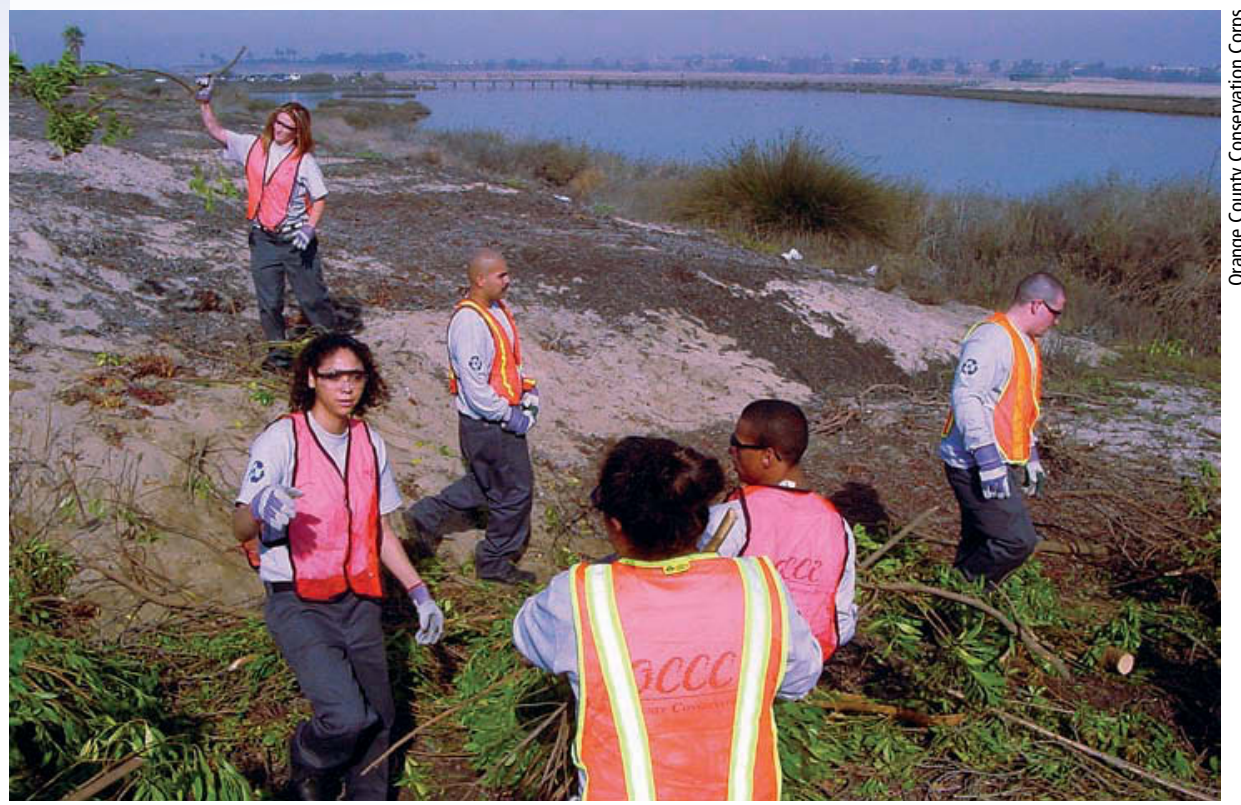

Members of the Orange County Conservation Corps help remove nonnative plants and debris from coastal sand dunes on the Bolsa Chica Ecological Reserve in Huntington Beach, and restore the area with native plants. Federal funding for workforce development programs has declined from \$24 billion in 1978 to about \$6 billion in 2000.

economy .... It is not what we own that counts, it is what we do." Given the changing nature of jobs in the new information economy, Reich argues for rethinking how we invest in public education and worker training. For example, today's workers often need to learn quickly on the job, think outside of the box, and understand other people's needs (Reich 2002), skills not measured by typical standardized tests.

Reich's vision for our nation's workforce provides a fitting vantage point for examining the findings of the recent UC Davis evaluation of workforce development programs for California youth, funded under the 1998 federal Workforce Investment Act (WIA) (see box, page 41). This evaluation found that the WIA's emphasis on comprehensive youth services results in higher quality programs, but that unfortunately these programs are reaching fewer and fewer youth due to a decline in federal funding (Lamming et al. 2006). Total public expenditures for training and retraining low-skilled workers diminished from a peak of \$24 billion in 1978 to $\$ 7$ billion in 1998 and a little over $\$ 6$ billion in 2000, a $75 \%$ cut (Giloth 2004).
These federal cuts have hit California hard. Between 2001 and 2005, WIA allocations declined an average of $26 \%$ for 40 of the state's 50 local workforce areas (Lemp and Campbell 2005). These workforce areas are local administrative bodies that receive federal and state funding to implement workforce development programs. A 2006 survey found that two-thirds of the local workforce areas in California had experienced reductions in their allocations for youth programs over a 3-year period from 2003 to 2006 (Campbell et al. 2006).

These cutbacks exacerbate a growing youth workforce development crisis in California. A 2003 study reported that 638,000 California young people aged 16 to 24 years were out of school and out of work (Sum 2003). Too many of these youth end up in the prison system or, at best, in low-wage work that does not lift them or their families out of poverty. Existing youth workforce development programs reach a very small fraction of those in need. For example, a 2004 study reported that there were approximately 93,000 out-of-school, out-of-work youth in Los Angeles (Fogg and Harrington 2004). However, WIAfunded workforce programs enrolled 


\section{Youth programs emphasize comprehensive services}

Youth workforce development programs are designed for young people 14 to 21 years old who face substantial obstacles to employment. These programs depend primarily on funding received under the 1998 federal Workforce Investment Act (WIA). Since 2000, state and local Youth Councils and Workforce Investment Boards have implemented such programs in California. Services are provided through contractors, including nonprofit organizations, city school districts, county offices of education, faith-related organizations and private firms.

Reflecting the belief of Congress that the "trend of providing short-term programs for youth is unacceptable" (Brustein and Knight 1998), WIA-funded youth programs have 10 required program elements: (1) tutoring, study-skills training and instruction leading to secondary school completion; (2) alternative secondary school offerings; (3) summer employment opportunities directly linked to academic and occupational learning; (4) paid and unpaid work experiences including internships and job shadowing; (5) occupational skills training; (6) leadership development opportunities;

(7) supportive services; (8) adult mentoring; (9) followup services; and (10) comprehensive guidance.

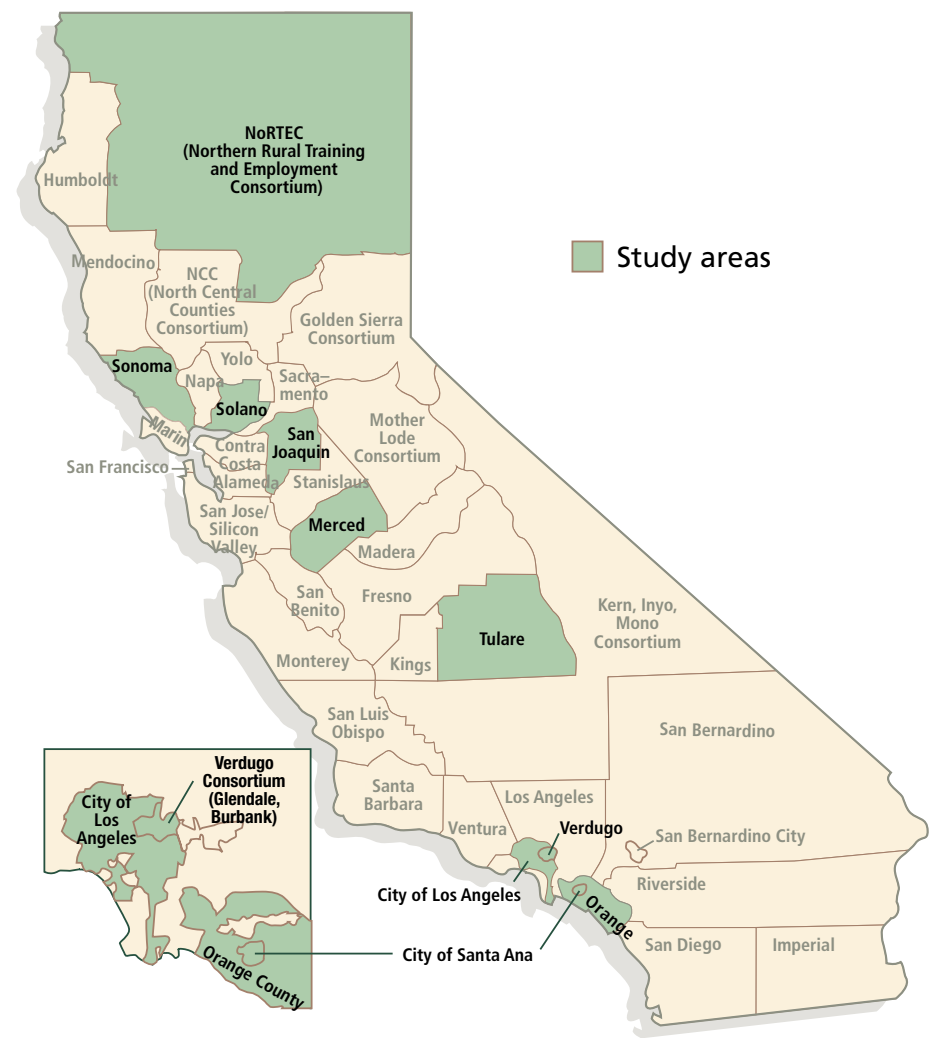

Fig. 1. Local workforce areas selected for case study sample. only 2,232 youth during the 2005-2006 program year due to insufficient funds (personal communication, California Employment Development Department administrative data).

A key goal of the UC Davis evaluation was to identify strategies that local workforce officials have developed to meet the broader WIA service mandate, despite decreased federal funding. We focus on one promising strategy worthy of replication, in which youth engage in skill- and pride-generating public work projects. Boyte and Kari (1996) defined public work as "work with public purposes, work by a public, [and] work in public settings." While Boyte and Kari were primarily interested in using public work to introduce youth to the craft of citizenship, local workforce officials in California are also finding that it is a powerful tool to teach occupational skills, as well as work readiness attitudes such as teamwork, customer service and reliability.

\section{Youth workforce programs}

To study the implementation of WIA-funded youth workforce development programs in California, a team of UC Davis and UC Cooperative
Extension (UCCE) researchers partnered with the California Workforce Investment Board and the Employment Development Department between March 2005 and September 2006. The research team included three UCCE 4-H youth development advisors as well as UC Davis faculty and researchers with expertise in community development and public policy.

The purpose of this research was to investigate how WIA provisions for youth programs are being implemented in local workforce areas, to gain an understanding of what is working and what is not, and to make this information available to decision-makers, primarily at the state level. The research design, approved by state officials and an evaluation advisory committee of state agency representatives, emphasized case studies of local implementation using qualitative analysis techniques and methods.

A key goal was to identify patterns and trends in the service delivery motifs that local areas were employing, particularly those that local stakeholders viewed as successful or promising. Since WIA legislation grants local workforce areas considerable discretion to tailor programs to local needs and circumstances, state officials were interested in learning more about how local discretion was being exercised. Consistent with the "field network approach" used in many studies of public policy implementation (Nathan 2000), the final product was a detailed cross-case analysis comparing implementation across local workforce areas and identifying policy and programmatic recommendations (Lamming et al. 2006).

The findings reported here represent just one component of this larger youth workforce evaluation, which in turn was part of an even broader evaluation of the workforce development system in California based on more than 400 interviews, observations, review of documents and analysis of administrative data (Campbell et al. 2006).

Sample selection. California is divided into 50 local workforce areas, which comprise cities, counties or consortia of cities or counties (fig. 1). We selected 10 of these areas to maximize variation in location, economic conditions, size, administrative structure and conditions for youth (table 1). The 10 study areas were: (1) NoRTEC 

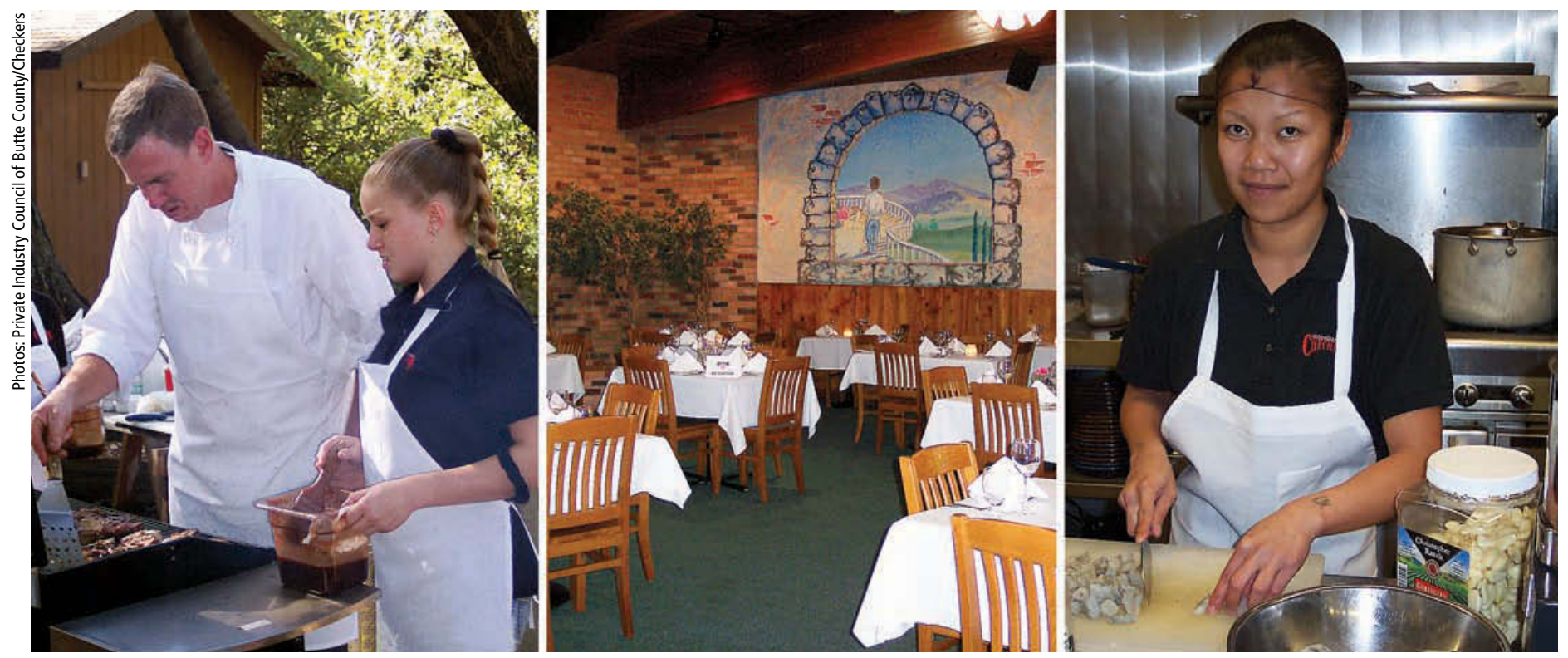

Checkers, a popular Italian restaurant in Oroville, is Butte County's primary training program for out-of-school youth who are eligible for Workforce Investment Act assistance. Left, instructor Tim Yarbrough shows Monica Rodriguez how to prepare BBQ Italian ribs on an outdoor grill; center, the restaurant interior; right, Kristy Saechao prepares shrimp for seafood crespelle.

(Northern Rural Training and Employment Consortium, comprised of Del

Norte, Lassen, Modoc, Plumas, Shasta, Siskiyou, Sutter, Tehama and Trinity counties); the counties of (2) Merced,

(3) Orange, (4) San Joaquin, (5) Solano, (6) Sonoma and (7) Tulare; and the cities of (8) Los Angeles, (9) Santa Ana and (10) Glendale and Burbank (Verdugo Consortium). Collectively, these areas serve about one-third of the state's population and receive almost $30 \%$ of California's WIA allocations.

Case studies. Research team members prepared case studies of local WIA youth programs and the Youth Councils appointed to provide direction for these programs. Youth council members include representatives of youth-serving agencies, public housing authorities, parents of WIA-eligible youth, and others with interest or expertise in youth policy. Members are appointed by the local Workforce Investment Board in cooperation with local elected officials. We observed at least one Youth Council meeting in nine of the 10 workforce areas studied, reviewed documents such as Youth Council minutes and agendas, explored Youth Council and youth program Web sites, and developed profiles of each workforce area using data from local informants and official sources (such as U.S. Census data, city and county government statistics).

In addition, we typically interviewed eight to 12 key informants in each lo- cal workforce area, including: the lead Workforce Investment Board staff person for youth; the chair of the Youth Council; up to three members of the Youth Council, including at least one youth when possible; and representatives of at least two youth services providers that receive subcontracts from local Workforce Investment Boards.

Across the 10 local workforce areas studied, the research team conducted 104 confidential interviews between March 2005 and May 2006. Research team members followed a common interview protocol to ensure the comparability of responses, but were encouraged to adapt questions to learn as much as possible about unique individuals, situations and perspectives.
Questions covered a wide range of topics, including the Youth Council's composition and scope of responsibilities, the nature of funded contractors and their services, the mechanisms in place to encourage collaboration among local youth-serving organizations, and the respondents' views on what had and had not worked well during local implementation of WIA youth provisions.

Qualitative analysis. All interviews were tape-recorded and transcribed. Making use of qualitative analysis software (QSR N6), we then performed a content analysis on the transcripts and field notes, looking for common themes, patterns and issues both within and across the 10 local workforce areas.

\begin{tabular}{|c|c|c|c|c|c|}
\hline County/area & $\begin{array}{l}\text { Total } \\
\text { population } \\
(1 / 1 / 2005)\end{array}$ & $\begin{array}{l}\text { Youth up } \\
\text { to age } 17 \\
(2005)\end{array}$ & $\begin{array}{l}\text { Child } \\
\text { poverty } \\
\text { rate }(2002)\end{array}$ & $\begin{array}{l}\text { Out-of-school, } \\
\text { out-of-work youth } \\
\text { ages 16-19 (2000) }\end{array}$ & $\begin{array}{c}\text { Youth meeting UC/CSU } \\
\text { entrance requirements } \\
\text { (2002-2004) }\end{array}$ \\
\hline \multicolumn{6}{|c|}{...... no. } \\
\hline Los Angeles* & $10,166,417$ & $2,779,941$ & 25.3 & 10.7 & 36.3 \\
\hline Merced & 241,464 & 77,825 & 26.2 & 12.0 & 22.0 \\
\hline NoRTEC $†$ & 606,555 & 110,818 & 20.0 & 9.2 & 27.9 \\
\hline Orange & $3,047,054$ & 800,650 & 14.2 & 7.6 & 36.0 \\
\hline San Joaquin & 655,319 & 195,328 & 19.6 & 11.7 & 30.4 \\
\hline Solano & 420,307 & 111,382 & 10.2 & 7.9 & 27.8 \\
\hline Sonoma & 477,697 & 109,966 & 9.7 & 7.9 & 35.6 \\
\hline Tulare & 411,701 & 131,883 & 32.1 & 12.4 & 23.8 \\
\hline
\end{tabular}


- In Tehama County, Workforce One members learn job skills in basic construction, home maintenance and landscaping. Earning minimum wage, they have done community-service jobs such as restoring parks and planting trees. Top, Corvin Johnston repairs a pipe. Bottom, Charlotte McNamara operates a drill press.

Given the funding cuts and mandate to provide more holistic services, we were particularly interested in whether local areas were finding ways to leverage their limited resources through innovative programs or partnerships. All interviewees were asked to identify local programs, collaborations or initiatives that they considered highly successful. As our fieldwork progressed, we identified programs that had been nominated by multiple respondents. We then created program profiles by interviewing key staff and gathering perspectives from local observers not directly connected with the program.

In some local workforce areas, we were able to directly observe youth program activities and conduct focus groups with participating youths (table 2). We conducted eight focus groups with a total of 53 youth between October 2005 and April 2006. We questioned these youth about their aspirations for future employment, experience with WIA programs, exposure to vocational information in school, and sources of information about jobs. We then analyzed the notes and transcripts from the focus groups, finding that many youth had positive or even "life changing" experiences with WIA programs.

\section{What works, and doesn't work}

As we reviewed the data, it became clear that certain WIA-related innovations were relatively ineffective, while programs that engaged youth in public work were particularly promising. For example, while local Youth Councils serve as valuable networking bodies, in most local areas they have not lived up to the hope that they would spur new efficiencies by serving as a focal point for the integration of youth services. In fact, only slightly more than half of local area executive directors surveyed in 2006 indicated that they would even retain their Youth Council if WIA reauthorization no longer required it (Campbell et al. 2006).

Another disappointment concerning local implementation involved work readiness certificates, which are a way of credentialing youth as potential em- ployees based on the expectations of the local business community. Despite the state-level attention this approach was receiving as a promising means of partnering with local businesses, we found that none of the case study areas with these certificates had managed to roll out a viable program. Impediments included the practical difficulty of informing and enlisting a sufficient number of employers and youth, as well as philosophical differences, such as how academic the standards should be, and whether the focus should be on WIAeligible youth or all youth.

By contrast, in four of the 10 local workforce areas, we encountered lead youth program staff who were excited about public work projects. These programs evolved through local innovation rather than as a result of federal mandates, so not all local areas have tried them. The workforce areas that had launched such public work initiatives found that they provide youth with valuable work experience and consistent adult support, and have been able to extend the reach of limited workforce development dollars by leveraging funds from local public agencies or

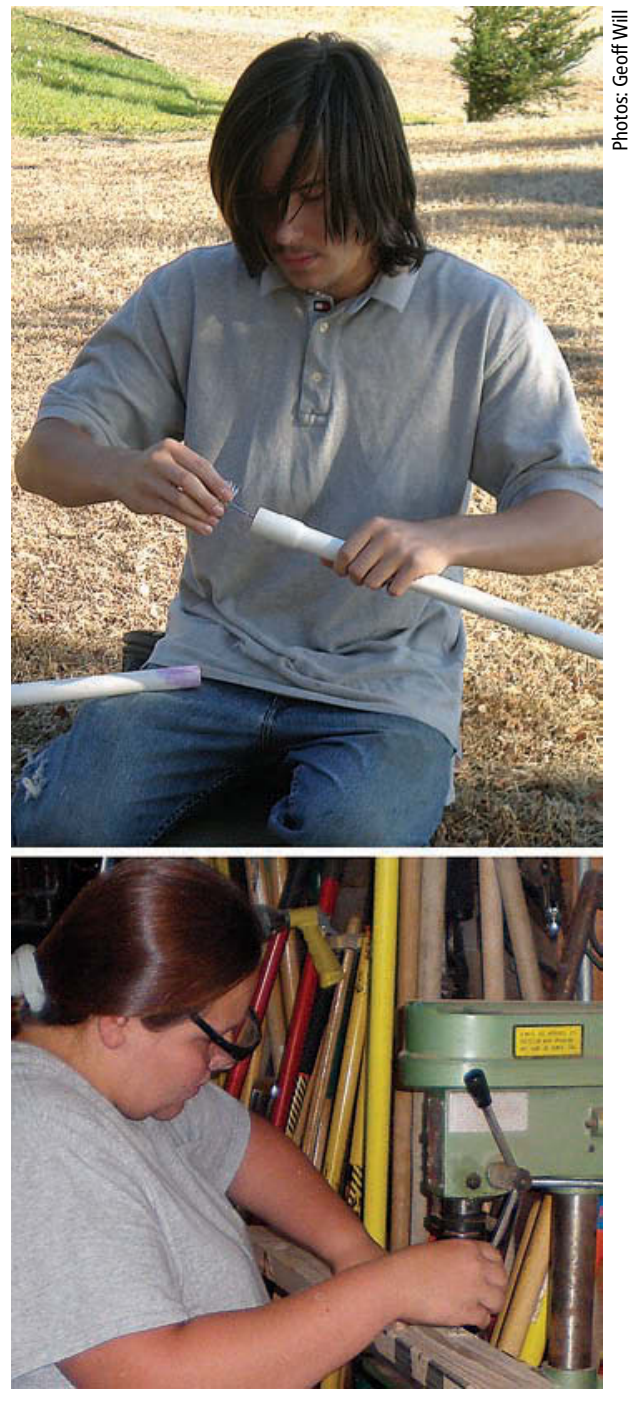

\begin{tabular}{|c|c|c|c|c|}
\hline Location* & Number & Gender & Race & Age (years) \\
\hline Los Angeles/Watts & 7 & $\begin{array}{l}6 \text { female } \\
1 \text { male }\end{array}$ & $\begin{array}{l}6 \text { black } \\
1 \text { Latino }\end{array}$ & $18-22$ \\
\hline Los Angeles/Culver City & 9 & $\begin{array}{l}2 \text { female } \\
7 \text { male }\end{array}$ & $\begin{array}{l}4 \text { black } \\
1 \text { Latino } \\
4 \text { Asian }\end{array}$ & $18-20$ \\
\hline Merced County & 11 & $\begin{array}{l}10 \text { female } \\
1 \text { male }\end{array}$ & $\begin{array}{l}8 \text { Latino } \\
2 \text { Asian } \\
1 \text { white }\end{array}$ & $18-23$ \\
\hline NoRTEC (Butte County) & 9 & $\begin{array}{l}8 \text { female } \\
1 \text { male }\end{array}$ & $\begin{array}{l}1 \text { black } \\
3 \text { white } \\
3 \text { Latino } \\
2 \text { Asian/Pacific Islander }\end{array}$ & $18-20$ \\
\hline San Joaquin County & 4 & $\begin{array}{l}2 \text { female } \\
2 \text { male }\end{array}$ & $\begin{array}{l}3 \text { black } \\
1 \text { white }\end{array}$ & $18-21$ \\
\hline Solano County & 4 & $\begin{array}{l}3 \text { female } \\
1 \text { male }\end{array}$ & $\begin{array}{l}3 \text { black } \\
1 \text { Latino }\end{array}$ & 18 \\
\hline Sonoma County & 2 & $\begin{array}{l}1 \text { female } \\
1 \text { male }\end{array}$ & 2 white & $18 \& 20$ \\
\hline Tulare County & 7 & $\begin{array}{l}4 \text { female } \\
3 \text { male }\end{array}$ & $\begin{array}{l}5 \text { Latino/Hispanic } \\
1 \text { Asian } \\
1 \text { white }\end{array}$ & $18-21$ \\
\hline Totals & 53 & $\begin{array}{l}36 \text { female } \\
17 \text { male }\end{array}$ & $\begin{array}{l}19 \text { Latino } \\
17 \text { black } \\
9 \text { Asian/Pacific Islander } \\
8 \text { white }\end{array}$ & $18-23$ \\
\hline
\end{tabular}


TABLE 3. Youth public work programs studied

businesses. In addition, some of these public work initiatives have fee-forservice arrangements that can funnel income back into the program.

The particular foci or profiles of the public work projects that we studied varied (table 3), but nonetheless our analysis identified three key program elements: (1) a holistic approach that combines employment preparation with social services and personal support; (2) structures that group youth in cohorts where they work/learn together, combining paid work with the chance to build self-confidence and learn what it takes to be a good employee; and (3) caring adult supervision of significant duration that combines discipline and support in appropriate measures.

These program features, which go well beyond what was typically present in summer jobs programs offered under the Job Training Partnership Act (the federal predecessor to the WIA), are consistent with Mangum's (2000) literature review, which identified features associated with successful youth workforce programs: enrollment duration of at least 1 year; integrated combinations of basic education, skills training and on-the-job training; a visible connection to jobs of promise; mentoring by respected adults; opportunities for highprofile community service; possibilities for further educational advancement upon demonstrated success; and youth sharing in program decision-making responsibilities, allowing a sense of empowerment that is greater than that available through antisocial activities.

Although youth workforce programs often involve complex collaborations among a variety of government and nonprofit service providers, the exemplary cases that we identified tended to have discrete identities, cultures and program boundaries. For youth participants, joining one of these programs provided an identity that typically became a source of pride, similar to what other youth might experience by being part of a sports team, band, or even a gang.

\begin{tabular}{|c|c|c|c|c|}
\hline $\begin{array}{l}\text { Local Workforce } \\
\text { Investment Area }\end{array}$ & Program & Type of work experience & $\begin{array}{l}\text { Lead service } \\
\text { provider }\end{array}$ & $\begin{array}{l}\text { Type of } \\
\text { organization }\end{array}$ \\
\hline Orange County & Conservation Corps & $\begin{array}{l}\text { Work crews perform } \\
\text { recycling and community } \\
\text { improvement projects }\end{array}$ & $\begin{array}{l}\text { Orange County } \\
\text { Conservation Corps }\end{array}$ & Nonprofit \\
\hline \multirow[t]{2}{*}{ NORTEC } & Checkers & Team runs restaurant & $\begin{array}{l}\text { Butte County } \\
\text { Private Industry } \\
\text { Council }\end{array}$ & Nonprofit \\
\hline & Workforce One & $\begin{array}{l}\text { Teams do community } \\
\text { improvement projects }\end{array}$ & $\begin{array}{l}\text { Tehama County Job } \\
\text { Training Center }\end{array}$ & Nonprofit \\
\hline Santa Ana & Taller San Jose & $\begin{array}{l}\text { Apprenticeships in } \\
\text { construction, medical and } \\
\text { IT fields }\end{array}$ & Sisters of St. Joseph & $\begin{array}{l}\text { Faith-related } \\
\text { nonprofit }\end{array}$ \\
\hline $\begin{array}{l}\text { Verdugo } \\
\text { Consortium }\end{array}$ & $\begin{array}{l}\text { Summer Brush } \\
\text { Clearance Program }\end{array}$ & $\begin{array}{l}\text { Crews clean hillside brush } \\
\text { for wildfire prevention }\end{array}$ & $\begin{array}{l}\text { Glendale Youth } \\
\text { Alliance }\end{array}$ & Nonprofit \\
\hline
\end{tabular}

\section{Holistic, developmental approach}

Successful public work programs typically featured a holistic, developmental approach, working with youth in age-appropriate ways and developing their skill sets patiently over time. Specific program elements included mentoring and employment-related counseling, but also services to help youth overcome barriers to success such as drug addiction, low self-esteem, unhealthy relationships, criminal histories and mental health problems. Most local service providers applauded the fact that the WIA's required elements gave them greater flexibility to use workforce funds to provide vital social services. "I don't think we would have ever funded something like drug counseling services before ... [Now] we're not just resumes and applications; it's your mental health, and all that other stuff that's going along with it," said a Los Angeles area provider. Likewise another south-state provider emphasized why it is essential to first overcome barriers before reaching other goals: “How in the heck am I going to send a kid that's all screwed up on methamphetamines, or a girl that's being beat up by her boyfriend, to a job? We have to work on those barriers first."

An example of the holistic approach is the Glendale Youth Alliance, a primary youth services contractor for the Verdugo Consortium local workforce area. Glendale Youth Alliance is a nonprofit organization that was started when the community came together to address a nascent gang problem. They began by putting youth to work in supervised crews that cleared brush from hillsides as part of the city's wild- fire prevention efforts. The alliance has since developed programs that give youth increasing experience and responsibility working in local government offices, nonprofits, hospitals and businesses. The alliance pays the youth's wages except in the most-skilled jobs, where their employers pay. As an additional incentive for businesses to participate, the City of Glendale underwrites the cost of workers' compensation.

The lure of employment is the initial draw for most youth, but in order to work they must be in school and maintain an acceptable grade point average, or be enrolled in a certificated program or vocational school. Each participant has a counselor/mentor that works with him or her on a personal basis. Glendale Youth Alliance staff see mentoring as a key component. "We don't just attack the work part. We attack the whole person because in any work environment, the whole person comes to work," a staff member said.

The holistic approach also is evident in Glendale Youth Alliance's Summer Brush Clearance Program for 14- and 15-year-olds. Before working in the hills clearing brush, these youth get 3 weeks of intense life and job skills training, 4 days a week, 4 hours a day. They also learn CPR and first aid, receive on-site tool training, and go on field trips such as to the Museum of Tolerance to learn about conflict resolution.

\section{Group work experiences}

A second element of successful youth public work programs was creating a structured experience with youth working in cohorts and staff working alongside them to ensure that they learn key work attitudes and skills. 


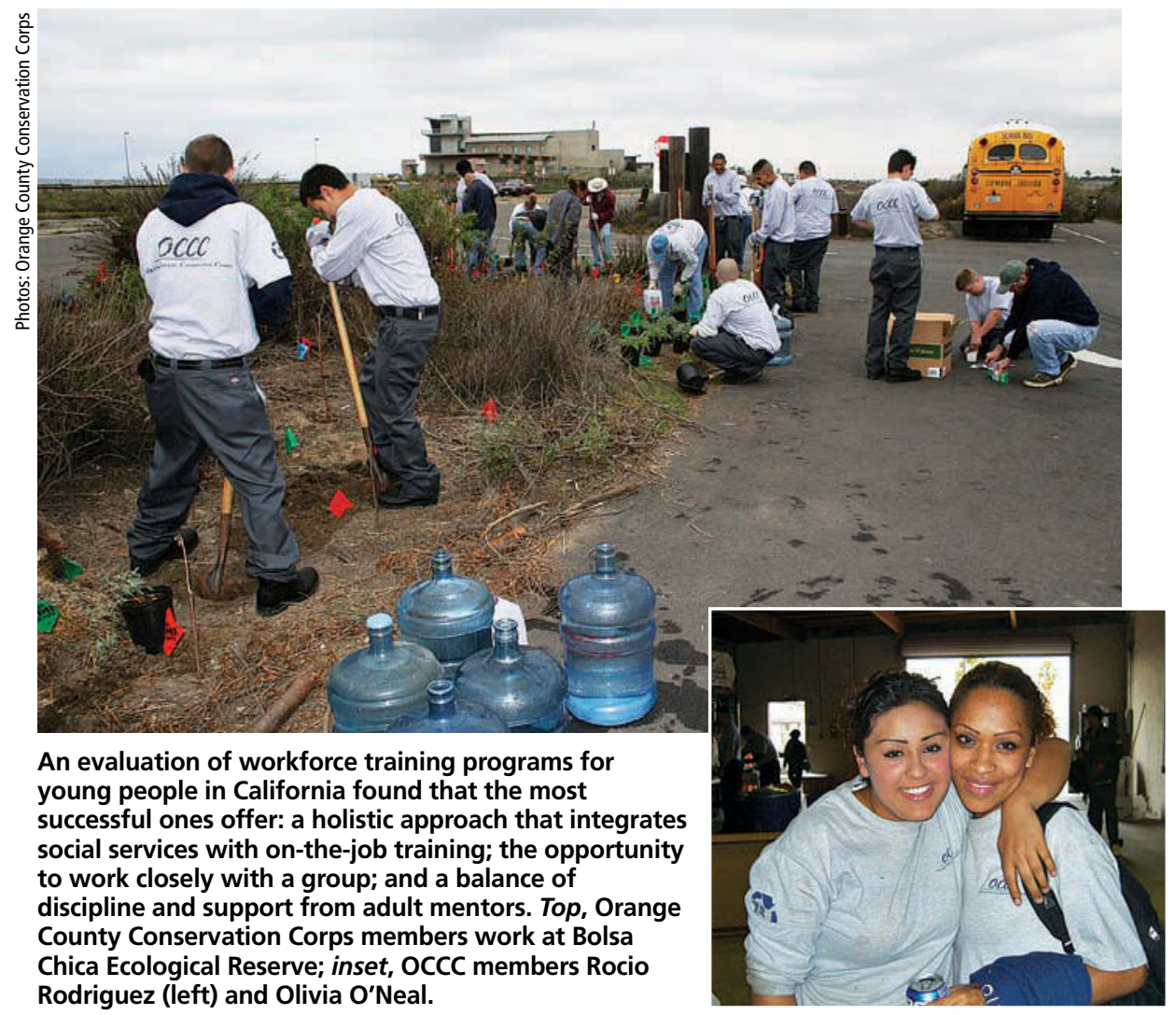

The value of a caring, continuous adult relationship to a young person cannot be overestimated.

Originally, Workforce One performed community-service work only, such as refinishing and painting the city pool, planting trees as part of a downtown beautification effort, and rebuilding the dugouts, fences and restrooms at the Little League ballpark. An unexpected outcome was the sense of accomplishment and civic pride that the youth experienced as they saw the fruits of their labor, and as they received accolades from city councils, county department heads and community leaders (Boyte 2004).

As the reputation of Workforce One grew, requests for their assistance started coming in from private-sector businesses and homeowners struggling to find trustworthy day laborers. Filling this niche, Workforce One

In some cases, these projects generated funds that are funneled back to support the program, as illustrated by Checkers restaurant in Butte County and Workforce One in Tehama County, both part of the NoRTEC.

Checkers restaurant. Checkers is a popular restaurant in Oroville that serves elegant Italian food. It is also Butte County's primary program for WIA-eligible, out-of-school youth, though its patrons might never guess that it was started specifically for that purpose. When it opened in 2001, the idea was to introduce WIA-enrolled youth to the world of work in what the program director hoped would become a self-sustaining business enterprise. Checkers has surpassed all expectations, offering work experience and a character-building program for 18- to 21-year-olds, while generating an annual six-figure income that helps support this and other programs. Checkers is branching out, doing catering for large social affairs and gaining even more positive publicity and revenue.

The 18 youth participants are paid minimum wage as they take on all the jobs in the restaurant, from greeting to cooking to serving to cleaning up. While performing the various jobs, they learn about customer service and how to present themselves as employees. They also are required to pass the state sanitation course. The program is designed to give each participant 1,000 hours of experience, and one of the most difficult administrative duties is getting the kids to leave the program when it is time for them to do so.

Workforce One. Workforce One is a crew of older youth (ages 18-21) with one supervisor assigned to five participants. The supervisors function as boss, trainer, mentor, coach, parent, counselor and drill sergeant as the crews perform a variety of general labor, maintenance and groundskeeping jobs. Crew members acquire job skills including basic construction and repairs, painting, plumbing, electrical, horticulture, use of tools and safety; they are also taught the behaviors, attitudes and responses that employers expect. They receive minimum wage and are expected to meet work standards for productivity, quality, attendance and following instructions. Work-related mistakes and "soft skill" problems (such as communication issues, relationship problems) are approached as learning opportunities, but participants who do not respond to instruction and warnings must then face the real-world consequences of being suspended or fired. regularly does minor sprinkler and fence repair, pruning and planting, painting and simple building repairs. Although crews continue to provide community-service work at no charge, word-of-mouth brings in a steady stream of paying customers. After one year, Workforce One was generating enough revenue to cover the wages and payroll costs for a crew of five fulltime workers.

\section{Discipline and support}

A number of the youth workforce program leaders we interviewed emphasized that a healthy balance of discipline and support is structured into their programs. For example, a staff member at Glendale Youth Alliance described his summer brush-clearing program as a "boot camp" that also provides the positive group experience that teens crave: "It's very fun, though it's very rigid. There is a hard start time and if you miss it three times, you're out. [But we also] have 'Team of the Week' and 'Worker of the Week."'

Another example of a program featuring discipline and support is the Orange County Conservation Corps, an Anaheim-based, countywide nonprofit organization with a $\$ 3.5$ million annual 
budget. The Corps features a structured experience in which youth do recycling and other community improvement projects. Youth work in crews with supervisors, wear uniforms and are transported in Corps vans.

Corps members maintain a highly structured 40-hour week, with 32 hours of work and 8 hours of school. Nearly $90 \%$ lack a high school credential and attend the Corps-run charter high school. The rest receive pre-employment and other skills training. They are paid between minimum wage and $\$ 9.50$ per hour, and are eligible for better jobs in the Corps and higher pay if they do well. However, Corps participants are dismissed if they step out of line too many times, although they are allowed one second chance to return to the program. A Corps representative said: "We take a very employer-like approach. They get monthly evaluations. They can get merit raises, but there is nothing automatic."

Relationships with WIA-funded staff give youth the opportunity to grow and develop. Because the approach emphasizes long-term nurture as opposed to episodic encounters, these relationships can last for months or even years. The value of caring, continuous adult relationships to young people cannot be overestimated, particularly if relationships with their parents are problematic.

\section{Benefits to youth and society}

The WIA provision for a comprehensive approach to youth development has led local workforce officials to increase the variety and depth of youth services. But because the mandate for increased quality of service has not been supported by a corresponding increase in funding, fewer youth can benefit from WIA programs. The answer, as many previous studies have concluded, is not to shortchange the quality of services, but rather to increase the public investment in workforce programs (Giloth 2004; Mangum 2000; Reich 1991).

Our review of youth workforce programs found that public work projects are particularly promising. These efforts incorporate many features associated with successful program outcomes.
They inspire high levels of commitment from both participating youth and workforce staff, create tangible public benefits such as fire protection and clean parks, and attract additional financial resources that leverage limited funding.

It is important to keep in mind that no single approach can satisfy the needs of California's diverse youth population. Public work projects are especially successful for youth who are willing and able to make a long-term commitment. However, these projects are less appealing to youth who want or need immediate employment. This is one of many reasons why local workforce officials still view short-term summer jobs programs as a necessary component of their overall efforts, despite their limitations as a tool for youth workforce development.

Every youth that the WIA system can put on the path to secure employment is a youth less likely to burden the state later with social services or prison expenses. However, the rationale for these programs is much broader. By

\section{References}

Boyte HC. 2004. Everyday Politics: Reconnecting Citizens and Public Life. Philadelphia: Univ Penn Pr. $239 \mathrm{p}$.

Boyte HC, Kari N. 1996. Building America: The Democratic Promise of Public Work. Philadelphia: Temple Univ Pr. 255 p.

Brustein M, Knight R. 1998. A Guide to the Workforce Investment Act of 1998. National Association of Private Industry Councils, Washington, DC. $62 \mathrm{p}$.

Campbell D, Lemp C, Treiber J. 2006. WIA Implementation in California: Findings and Recommendations. Final Report, UC Davis Evaluation of California's Workforce Investment System. California Communities Program, UC Davis. http://ucce.ucdavis.edu/files/ filelibrary/5089/33964.pdf.

[CDF] California Department of Finance. 2006. E-1 Population Estimates for Cities, Counties and the State with Annual Percent Change - January 1, 2005 and 2006. Sacramento, CA. May 2006.

Children Now. 2005. California County Data Book 2005. Children Now, Oakland, CA. http:// publications.childrennow.org/publications/invest/ databook_2005.cfm.

Fogg N, Harrington P. 2004. One out of Five: A Report on Out of School and Out of Work Youth in Los Angeles and Long Beach. Center for Labor Market Studies, Northeastern Univ. Boston, MA (prepared for Los Angeles Workforce Investment Board).

Giloth RP (ed.). 2004. Workforce Intermediaries for the Twenty-first Century. Philadelphia: Temple Univ Pr. 424 p. teaching discipline, responsibility and work-related skills, exemplary youth public work programs contribute to the vital national challenge of mobilizing the skills of all our citizens, beginning with our most valuable potential asset our young people.

D. Campbell is Community Studies Specialist, UC Davis, and Director of the California Communities Program; J. Lamming is Junior Specialist, UC Davis; C. Lemp is Independent Research Consultant, Sonora; A. Brosnahan is 4-H Youth Development Advisor, UC Cooperative Extension (UCCE) San Joaquin County; C. Paterson is 4-H Youth Development Advisor and County Director, UCCE Solano County; and J. Pusey is retired 4-H Youth Development Advisor, UCCE Los Angeles County. Richard Ponzio, UC Davis Cooperative Extension specialist, served as Guest Associate Editor. This report was supported in part by funds provided by an evaluation contract between UC Davis and the California Workforce Investment Board (CWIB), as well as by a Core Issues Grant from the UC Division of Agriculture and Natural Resources. The analysis, interpretations and conclusions in this paper are the responsibility of the authors and not the CWIB.

Lamming J, Lemp C, Campbell D. 2006. The Workforce Investment Act and California Youth: Implementing Local Youth Councils and Youth Programs. Fourth Interim Report, UC Davis Evaluation of California's Workforce Investment System. California Communities Program, UC Davis. September 2006. http:// ucce.ucdavis.edu/files/filelibrary/5089/33969.pdf.

Lemp C, Campbell D. 2005. Survey of Local Workforce Investment Board Executive Directors Second Interim Report, UC Davis Evaluation of California's Workforce Investment System. California Communities Program, UC Davis. April 2005. http:// ucce.ucdavis.edu/files/filelibrary/5089/34141.pdf.

Mangum GL. 2000. Reflections on training policies and programs. In: Barnow B, King C (eds.). Improving the Odds: Increasing the Effectiveness of Publicly Funded Training. Washington, DC: Urban Inst Pr. p 293-333.

Nathan R. 2000. Social Science in Government: The Role of Policy Researchers. Albany, NY: Rockefeller Inst Pr. 213 p.

Reich RB. 1983. The Next American Frontier. New York: Penguin. 324 p.

Reich RB. 1991. The Work of Nations. New York: Knopf. 331 p.

Reich RB. 2002. I'll Be Short. Boston: Beacon Pr. $121 \mathrm{p}$.

Sum A. 2003. Leaving Young Workers Behind. National League of Cities, Institute for Youth, Education, and Families. Washington, DC 16 p. www.nlc.org/ASSETS/B427F9BF9AB748E7A1768C04C03405B6/IYEF_DY_Leaving_Young_ Workers_Behind.pdf. 